\title{
РЕЖИМИ ЖИТТЕДІЯЛЬНОСТІ ЯК ДЕТЕРМІНАНТИ ПОРУШЕНЬ ПСИХІКИ ТА ПОВЕДІНКИ У СІЛЬСЬКОГО НАСЕЛЕННЯ
}

\author{
ДУ “Український інститут стратегічних досліджень МОЗ України”, м. Київ \\ Острозька обласна психіатрична лікарня, Україна
}

\begin{abstract}
Мета: вивчити та проаналізувати режими життєдіяльності як детермінанти порушення психіки та поведінки у сільського дорослого населення.

Матеріали і методи. У ході виконання роботи використано наступні методи: статистичний - дані галузевої статистики Рівненської області за 2010-2013 рр.; соціологічний - за спеціально розробленою анкетою опитано 1200 сільських жителів області.

Результати. Встановлено, що детермінантами порушення психіки та поведінки можуть стати такі режими життєдіяльності: напружений та високонапружений режим дня з тривалістю активної частини робочого дня 9-10 годин, завантаженістю робочого часу на 80-90\%; пасивний фізичний відпочинок; недостатня тривалість нічного сну, з пізнім засинанням та раннім пробудженням.

Висновки. Важливе значення у розвитку порушень психіки та поведінки має режим життєдіяльності. Провідним фактором ризику розвитку порушень психіки та поведінки є якість та тривалість нічного сну.
\end{abstract}

КЛЮЧОВІ СЛОВА: сільське населення, режим життєдіяльності, порушення психіки та поведінки, детермінанти.

Психічне здоров'я та психічне благополуччя $€$ найважливішими складовими високого рівня якості життя, які дозволяють людині вважати своє життя повноцінним та значущим, бути активним і творчим членом суспільства. Високий рівень психічного здоров'я населення є важливим фактором соціальної єдності, продуктивної праці, суспільного спокою та стабільності оточуючого середовища [1;2]. Психічне, фізичне та соціальне здоров'я є важливими складовими життя, які тісно пов'язані між собою та залежать один від одного. їх взаємозв'язок свідчить, що психічне здоров'я є надзвичайно важливим для загального благополуччя окремих осіб, громад та країни в цілому [3;9].

За даними ВООЗ [5], психічні та поведінкові розлади є надзвичайно поширеними і вражають до 25\% всіх людей у певні періоди їхнього життя. Згідно з показником DALI [4], до 2020 року тягар розладів психіки та поведінки досягне 15\% від усіх хвороб.

В Україні на розлади психіки та поведінки страждає біля 250 осіб на 100 тис. населення, що є одним із найвищих рівнів серед країн Європи [6-8].

Мета роботи: вивчити та проаналізувати режими життєдіяльності як детермінанти порушення психіки та поведінки у сільського дорослого населення.

Матеріали і методи. У ході виконання роботи використано наступні методи: статистичний дані галузевої статистики Рівненської області за 2010-2013 рр. та соціологічний - за спеціально

(C) Н.С. Защик, 2014 розробленою анкетою опитано 1200 сільських жителів області. Отримані результати підлягали статистичній обробці з використанням програм Statistika 6.0 та MS Excel.

Результати дослідження та їх обговорення. Важливе значення в розвитку порушень психіки та поведінки має режим життєдіяльності. Виходячи з цього, на початку дослідження нами було вивчено та проведено порівняння частоти виникнення первинних випадків розладів психіки та поведінки серед дорослого сільського населення з різним рівнем психологічного навантаження протягом дня (табл. 1).

Порівняльна оцінка частоти первинних розладів психіки та поведінки серед дорослого сільського населення залежно від рівня навантаження режиму дня показала виразну залежність як показників виникнення первинних випадків розладів психіки та поведінки, так і коефіцієнта кореляції, від ступеня навантаження режиму дня населення. Так, найвищий коефіцієнт кореляції і показник частоти первинних випадків психічних розладів характерні для осіб, діяльність яких пов'язана з високим рівнем навантаження режиму дня. Частота виникнення первинних випадків розладів психіки та поведінки при напруженому робочому режимі у 7,07 разу вища, ніж при вільному режимі дня.

Важливе значення у підтримці високого рівня психічного здоров'я має відпочинок протягом доби. Як видно з табл. 2, найбільш позитивно на стан психіки та поведінки впливає активний у фізичному плані відпочинок з заняттям в тренажерному або фітнес-залі та відвідуванням басейну. 
Таблиця 1. Частота виникнення первинних випадків розладів психіки та поведінки серед дорослого сільського населення з різним рівнем психологічного навантаження протягом дня

\begin{tabular}{|c|c|c|}
\hline $\begin{array}{c}\text { Характеристика } \\
\text { режиму дня }\end{array}$ & $\begin{array}{c}\text { Частота виникнення первинних } \\
\text { випадків психічних розладів } \\
\text { на } 100 \text { тис. населення }\end{array}$ & $\begin{array}{c}\text { Коефіцієнт } \\
\text { кореляції }\end{array}$ \\
\hline $\begin{array}{l}\text { Режим дня вільний: самостійно планує свій } \\
\text { розпорядок дня; завантаженість робочого часу } \\
\text { становить } 20-50 \%\end{array}$ & $8,3 \pm 0,6$ & $\begin{array}{c}\mathrm{r}=-0,71 \\
\text { (зв'язок зворотній } \\
\text { сильний) }\end{array}$ \\
\hline $\begin{array}{l}\text { Режим дня мало напружений: тривалість активної } \\
\text { частини робочого дня 5-6 годин з можливістю } \\
\text { самостійного планування часу відпочинку; } \\
\text { завантаженість робочого часу становить } 40-60 \%\end{array}$ & $23,2 \pm 1,4$ & $\begin{array}{c}\mathrm{r}=-0,23 \\
\text { (зв'язок зворотній } \\
\text { слабкий) }\end{array}$ \\
\hline $\begin{array}{l}\text { Режим дня напружений та високонапружений: } \\
\text { тривалість активної частини робочого дня 9-10 } \\
\text { годин; завантаженість робочого часу становить } \\
80-90 \% \text {; надзвичайно організований }\end{array}$ & $58,7 \pm 4,9$ & $\begin{array}{l}\mathrm{r}=+0,91 \\
\text { (зв'язок прямий } \\
\text { сильний) }\end{array}$ \\
\hline
\end{tabular}

Таблиця 2. Частота виникнення первинних випадків розладів психіки та поведінки серед дорослого сільського населення залежно від форм відпочинку протягом доби

\begin{tabular}{|l|c|c|}
\hline \multicolumn{1}{|c|}{ Форма відпочинку протягом доби } & $\begin{array}{c}\text { Частота виникнення первинних } \\
\text { випадків психічних розладів } \\
\text { на } 100 \text { тис. населення }\end{array}$ & Коефіцієнт кореляції \\
\hline $\begin{array}{l}\text { Систематично пасивний фізичний відпочинок: } \\
\text { читання літератури, перегляд телепередач, } \\
\text { прослуховування радіо }\end{array}$ & $8,2 \pm 0,2$ & $\begin{array}{c}\text { r=+0, } \\
\text { (зв' язок прямий } \\
\text { середньої сили) }\end{array}$ \\
\hline $\begin{array}{l}\text { Щоденні піші (1,5-2 години) прогулянки на } \\
\text { свіжому повітрі у вільному режимі }\end{array}$ & $\begin{array}{c}\mathrm{r}=-0,40 \\
\text { (зв'язок зворотній } \\
\text { середньої сили) }\end{array}$ \\
\hline $\begin{array}{l}\text { Систематичний відпочинок релаксуючого } \\
\text { характеру з психорозвантажуючими } \\
\text { процедурами: 3-4 рази на тиждень відвідування } \\
\text { кабінетів ЛФК або масажу та психолога }\end{array}$ & $\begin{array}{c}\text { r=-0,86 } \\
\text { (зв'язок зворотній } \\
\text { сильний) }\end{array}$ \\
\hline $\begin{array}{l}\text { Систематичні фізично активні форми відпочинку: } \\
\text { щоденне плавання в басейні, 3-4 рази на тиждень } \\
\text { заняття в тренажерному залі або фітнес-залі }\end{array}$ & $0,5 \pm 0,02$ & \\
\hline
\end{tabular}

При цій формі відпочинку реєструється мінімальний рівень виникнення первинних випадків розладів психіки та поведінки серед дорослого сільського населення $(0,61 \pm 0,01$ випадку на 100000 населення). І навпаки - систематично пасивний фізичний відпочинок, при якому відбувається читання літератури, перегляд телепередач, прослуховування радіо, є фактором ризику для психічного здоров'я дорослого населення, оскільки при ньому рівень виникнення первинних випадків розладів психіки та поведінки серед дорослого сільського населення у 13,4 разу вищий, ніж при фізично активному відпочинку.

Особливе значення у забезпеченні психічного здоров'я населення має здоровий та достатньої тривалості нічний сон. Результати дослідження впливу різного режиму сну на частоту виникнення первинних випадків розладів психіки та поведінки серед дорослого сільського населення на- ведено в табл. 3. За даними таблиці можна зробити висновок, що різний режим сну по-різному впливає на стан психічного здоров'я сільського дорослого населення. Так, режим сну, при якому людина систематично лягає спати після півночі та піднімається не пізніше 5-5,5 години ранку, виступає виразним фактором ризику розвитку розладів психіки та поведінки. Серед людей, яким притаманний такий режим сну, показник частоти виникнення первинних випадків психічних розладів на 100 тис. населення у 7,8 разу вищий, ніж у людей, які мають сприятливий для психічного здоров'я режим сну: відхід до сну біля 21-22 години з відносно раннім (біля 6-6,5 години) пробудженням.

Враховуючи, що короткий сон виступає в ролі фактору ризику розвитку порушень психіки та поведінки, було вивчено частоту виникнення первинних випадків розладів психіки та поведінки 
Таблиця 3. Частота виникнення первинних випадків розладів психіки та поведінки серед дорослого сільського населення з різним режимом нічного сну

\begin{tabular}{|c|c|c|}
\hline Характеристика режиму сну & $\begin{array}{c}\text { Частота виникнення первинних } \\
\text { випадків психічних розладів на } \\
100 \text { тис. населення }\end{array}$ & Коефіцієнт кореляції \\
\hline $\begin{array}{l}\text { Режим виразно несприятливий. Відхід до } \\
\text { сну після півночі та раннє (біля } 5 \text { години) } \\
\text { пробудження. }\end{array}$ & $61,7 \pm 4,9$ & $\begin{array}{c}\mathrm{r}=+0,95 \\
\text { (зв'язок прямий сильний) }\end{array}$ \\
\hline $\begin{array}{l}\text { Режим несприятливий. Відхід до сну не } \\
\text { пізніше 22-ї години та раннє (біля } 5 \\
\text { години) пробудження }\end{array}$ & $25,3 \pm 3,0$ & $\begin{array}{c}\mathrm{r}=+0,53 \\
\text { (зв’язок прямий середньої } \\
\text { сили) }\end{array}$ \\
\hline $\begin{array}{l}\text { Режим сприятливий. Відхід до сну біля } \\
\text { 21-22 години та відносно раннє (біля 6- } \\
6,5 \text { години) пробудження }\end{array}$ & $7,9 \pm 1,0$ & $\begin{array}{c}\mathrm{r}=-0,14 \\
\text { (зв’ язок зворотній слабкий) }\end{array}$ \\
\hline
\end{tabular}

серед дорослого сільського населення, яке страждає та не страждає на нічне безсоння (табл. 4). З таблиці видно, що безсоння є причиною високого рівня первинних випадків психічних розладів
(45,3ะ3,2 на 100000 населення) при прямому сильному кореляційному зв'язку. І навпаки відсутність безсоння виступає в ролі фактору, який забезпечує збереження психічного здоров'я.

Таблиця 4. Частота виникнення первинних випадків розладів психіки та поведінки серед дорослого сільського населення, яке страждає та не страждає на нічне безсоння

\begin{tabular}{|l|c|c|}
\hline \multicolumn{1}{|c|}{ Характеристика режиму сну } & $\begin{array}{c}\text { Частота виникнення первинних } \\
\text { випадків психічних розладів на } \\
100 \text { тис. населення }\end{array}$ & $\begin{array}{c}\text { Коефіцієнт кореляції } \\
\text { Часто або постійно страждають на } \\
\text { нічне безсоння }\end{array}$ \\
\hline Не страждають на нічне безсоння & $45,3 \pm 3,2$ & $\begin{array}{c}\mathrm{r}=-0,73 \\
\text { (зв'язок прямий сильний) }\end{array}$ \\
\hline
\end{tabular}

Дані табл. 5 підтверджують гіпотезу, що режим нічного сну виступає як фактор ризику порушень психіки та поведінки, з одного боку, так і як фактор їх антиризику. При цьому тривалість нічного сну 8-9 годин є оптимальною і виступає як провідний фактор антиризику розвитку порушень психіки та поведінки та фактор збереження психічного здоров'я населення.

Таблиця 5. Частота виникнення первинних випадків розладів психіки та поведінки серед дорослого сільського населення з різною тривалістю здорового нічного сну

\begin{tabular}{|l|c|c|}
\hline \multicolumn{1}{|c|}{$\begin{array}{c}\text { Характеристика тривалості } \\
\text { здорового нічного сну }\end{array}$} & $\begin{array}{c}\text { Частота виникнення первинних } \\
\text { випадків психічних розладів на } \\
100 \text { тис. населення }\end{array}$ & $\begin{array}{c}\text { Коефіцієнт кореляції } \\
\begin{array}{l}\text { Тривалість нічного сну переважно } \\
8-9 \text { годин }\end{array}\end{array}$ \\
\hline $\begin{array}{l}\text { Тривалість нічного сну переважно } \\
6-7 \text { годин }\end{array}$ & $5,6 \pm 0,3$ & $\begin{array}{c}\mathrm{r}=+0,14 \\
\text { (зв'язок зворотній сильний) }\end{array}$ \\
\hline $\begin{array}{l}\text { Тривалість нічного сну переважно } \\
4,5-5 \text { годин }\end{array}$ & $11,2 \pm 1,1$ & $\begin{array}{c}\mathrm{r}=+0,85 \\
\text { (зв'язок прямий слабкий) }\end{array}$ \\
\hline
\end{tabular}

\section{Висновки}

Результати дослідження вказують на те, що певні режими життєдіяльності сільського дорослого населення можуть стати детермінантами порушення психіки та поведінки. До таких режимів життєдіяльності віднесені: напружений та високонапружений режим дня з тривалістю активної частини робочого дня 9-10 годин, завантаженістю робочого часу на 80-90\%; систематично пасив- ний фізичний відпочинок - читання літератури, перегляд телепередач, прослуховування радіо; відхід до сну після півночі та раннє (біля 5 години) пробудження; часте або постійне безсоння; тривалість нічного сну переважно 4,5-5 годин.

Перспективи подальших досліджень пов'язані з вивченням впливу способу життя сільського населення на розвиток порушень психіки та поведінки. 


\section{Список літератури}

1. Всемирная организация здравоохранения. Организация служб охраны психического здоровья в развивающихся странах : [шестнадцатый доклад Комитета экспертов ВОЗ по охране психического здоровья, декабрь 1974 г.]. - Женева : ВОЗ, 1975. - (Серия технических докладов ВОЗ, № 564).

2. Всесвітня організація охорони здоров'я. Організація служб охорони психічного здоров'я, грудень 1974 р. Женева : ВОЗ, 1975. - (Серія технічних доповідей ВООЗ, № 564).

3. Загородній С. М. Характристика саморуйнівної поведінки населення України / С. М. Загородній, В. М. Якимець // Україна. Здоров'я нації. - 2010. - № 2 - С. 35-39.

4. Охрана психического здоровья в мире / Р. Дежарле, Л. Айзенберг, Б. Гуд, А. Кляйнман. - К., 2001. - 576 с.

5. Психическое здоровье: новое понимание, новая надежда : [доклад о состоянии здравоохранения в мире, 2001 г.]. - Женева : ВОЗ, 2001. - 167 с.

6. Психічне здоров'я населення України : [інформ.-аналіт. огляд за 1990-2005 рр.]. - К., 2006. - 52 с.

7. Щорічна доповідь про результати діяльності системи охорони здоров'я України. 2008 рік / за ред. В. М. Князевича; МОЗ України, УІСД. - К., 2009. - 384 с.

8. Щорічна доповідь про стан здоров'я населення України та санітарно-епідемічну ситуацію. 2009 рік / за ред. 3. М. Митника. - К., 2010. - 447.

9. Юрьев Е. Системы психиатрической помощи: возможные модели управления и реформирования / Е. Юрьев // Вестн. ас. психиатров Украины. - 2003. - № 1-2. - С. 124-138.

\section{РЕЖИМЫ ЖИЗНЕДЕЯЛЬНОСТИ КАК ДЕТЕРМИНАНТЫ НАРУШЕНИЙ ПСИХИКИ И ПОВЕДЕНИЯ У СЕЛЬСКОГО НАСЕЛЕНИЯ}

H.C. Защик

ГУ “Украинский институт стратегических исследований МЗ Украины”, г. Киев

Острожская областная психиатрическая больница, Украина

Цель: изучить и проанализировать режимы жизнедеятельности как детерминанты нарушения психики и поведения у сельского взрослого населения.

Материалы и методы. В ходе выполнения работы использованы следующие методы: статистический - данные отраслевой статистики Ровенской области за 2010-2013 гг.; социологический - по специально разработанной анкете опрошено 1200 сельских жителей области.

Результаты. Установлено, что детерминантами нарушения психики и поведения могут стать такие режимы жизнедеятельности: напряженный и высоконапряженный режим дня с длительностью активной части рабочего дня 9-10 часов, загруженностью рабочего времени на 80-90\%; пассивный физический отдых; недостаточная длительность ночного сна, с поздним засыпанием и ранним пробуждением.

Выводы. Большое значение в развитии нарушений психики и поведения имеет режим жизнедеятельности. Ведущими факторами риска развития нарушений психики и поведения являются качество и длительность ночного сна.

Ключевые слова: сельское население, режим жизнедеятельности, нарушения психики и поведения, детерминанты.

\section{MODES OF LIFE AS DETERMINANTS OF MENTAL DISODERS AND BEHAVIOR AT RURAL POPULATION}

N.S. Zaschyk

PE "Ukrainian Institute of Strategic Researches MHC of Ukraine", Kyiv

Ostrog Regional Psychiatric Hospital, Ukraine

Purpose: to study and analyze modes of life as determinants of mental disorders and behavior at rural adult population.

Materials and methods. During performance of work the following methods are used: statistical - the data of branch statistics of the Rivne region for 2010-2013 years; sociological - under specially developed questionnaire 1200 countrymen of area are surveyed.

Results. It was established that determinants of mental disorders and behavior can become such modes of life: intense and high intense mode of day with duration of an active part of the working day 9-10 hours, workloadtime by $80-90 \%$; passive physical rest; insufficient duration of night sleep with late falling asleep and early awakening.

Conclusions. The great value in development of mental disorders and behavior has a mode of life. The leading risk factor for development of mental disorders and behavior is quality and duration of night sleep.

Key words: rural population, mode of life, mental disorders and behaviour, determinants.

Рукопис надійшов до редакції 25.10.2014 р.

Відомості про автора:

Защик Наталія Сергіївна - лікар-психіатр комунального закладу «Острозька обласна психіатрична лікарня» Рівненської обласної ради; служб. тел. +38(03654) 22874. 